\title{
Epitaph of Merki Found in Hambukol
}

\author{
ADAM ŁAJTAR
}

\begin{abstract}
The article offers editio princeps of a Greek epitaph discovered during the archaeological work of the Canadian Mission in Hambukol, a locality situated on the right-hand bank of the Nile, several kilometres to the north of Dongola, the capital of the Christian Nubian Kingdom of Makuria. The epitaph, constructed with the prayer 'God of spirits and all flesh', is dated to the ninth century on contextual and palaeographic grounds. It commemorates a certain Merki, who, according to the text, followed a splendid career in the state apparatus, which led from notarios to protodomestikos, i.e. the head of the royal office dealing with agriculture and fiscal matters.
\end{abstract}

Keywords: Christian Nubia, Hambukol, inscriptions, Kingdom of Makuria, administrative system, career models

Adam Łajtar, Institute of Archaeology, University of Warsaw, Warsaw; a.lajtar@uw.edu.pl; (D) 0000-0003-3842-2180

Hambukol is a village on the right bank of the Nile, $7 \mathrm{~km}$ to the north of the ruins of Dongola, the capital of the Nubian Christian Kingdom of Makuria. It is located on an alluvial stripe of land separating the river from its palaeochannel, called Letti Basin. In the time of the Kingdom of Makuria, Hambukol was an occupation site, the remains of which are hidden nowadays under two artificial hills called, appropriately, the Southern and the Northern Kom. Archaeological excavations carried out by the mission of the Royal Ontario Museum (ROM), Toronto, brought to light, on the Southern Kom, a spacious building of a disputable character amidst domestic architecture, ${ }^{1}$ and on the Northern Kom a church surrounded by graves. It is on the Northern Kom that three epitaphs, all of them in Greek, were discovered. The epitaphs were found in situ. The first of them, inscribed on a marble tray and commemorating Mariankuda, a tetrarch of Makuria (died AD 887), came to light in the church, within the sanctuary; the second belonging to a man whose name has not been preserved, on a tomb incorporated into a later burial structure located against the southeast wall of the church; and the third, commemorating a certain Merki, on a smaller cruciform tomb in the vicinity of the previous one. As a result of the division of finds between the

\footnotetext{
${ }^{1}$ For results of excavations on the Southern Kom, see: Grzymski et al. 2001.
} 


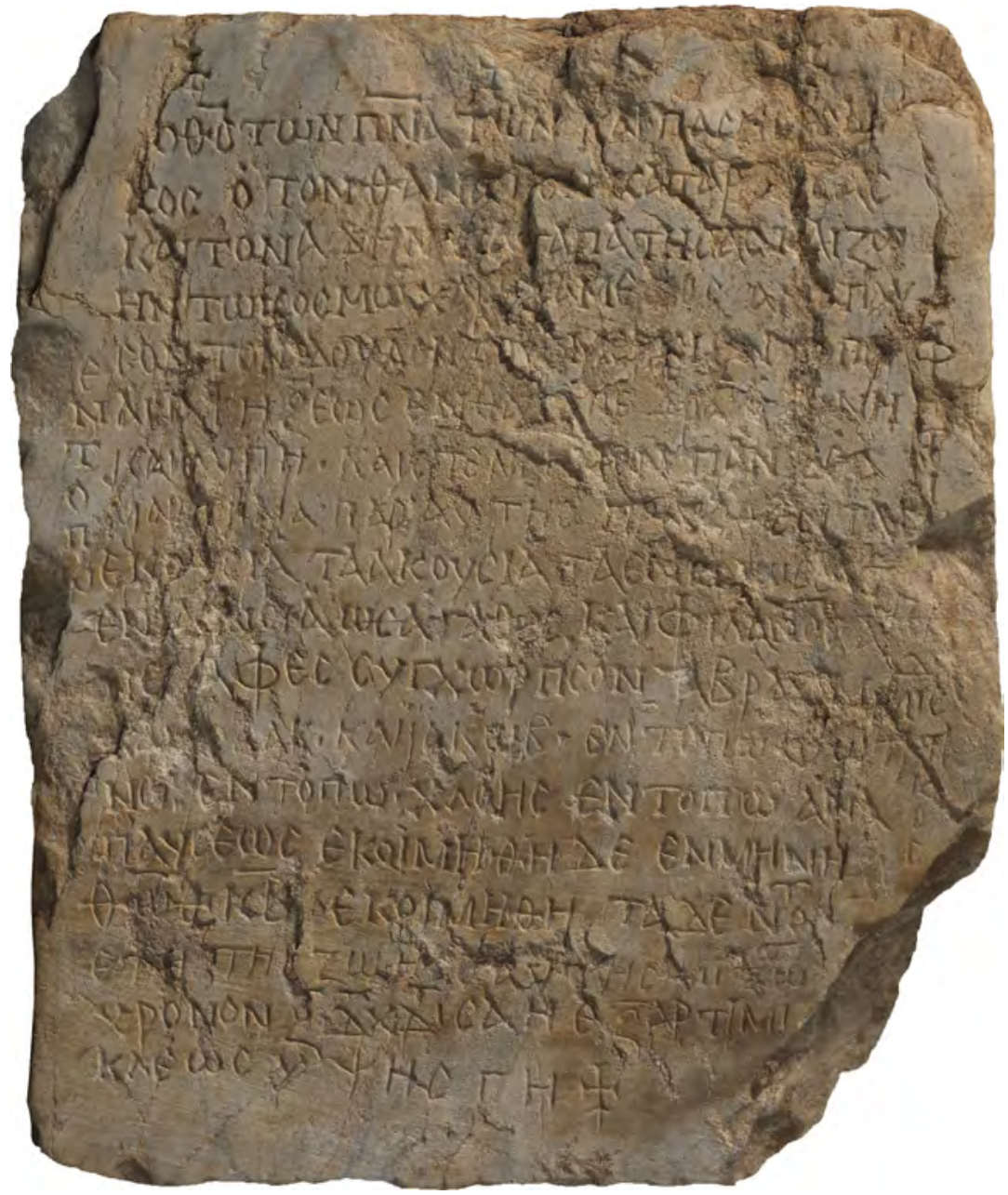

1. Greek epitaph of Merki found in Hambukol (ㄷ Royal Ontario Museum, Toronto).

Sudanese state and the ROM mission, the two first inscriptions went to the Sudan National Museum in Khartoum. They were published by me in the catalogue of Greek epigraphic holdings of the said museum. ${ }^{2}$ The third inscription was allotted to the Royal Ontario Museum in Toronto (inventory number 998.89.7) where I studied it in autopsy in summer 2007. The purpose of the present paper is to publish this interesting find.

The inscription stands on a roughly rectangular slab, $30.2 \mathrm{~cm}$ high, $25.5 \mathrm{~cm}$ wide, and $3.5-4.5 \mathrm{~cm}$ thick, made of white-cream marble with blue-gray stripes (Fig. 1). The lower right-hand corner of the slab is broken off, but as no letter is lacking here one can suppose that the breaking was older than the carving of the inscription. The edges of the slab are

\footnotetext{
${ }^{2}$ Łajtar 2003: nos 18, 19.
} 
chipped off and the stone surface is worn in many spots, especially in the upper righthand corner and in the centre of the left-hand side. The inscription has neither framing nor ruling, but it was executed quite nicely in even lines. The height of the letters varies between $0.5 \mathrm{~cm}$ (o in the word kó $\mu \omega$ in line 4 ) and $1.8 \mathrm{~cm}$ ( $\phi$ in line 12$)$. Palaeographically letters represent round epigraphic majuscules. The direct strokes of the letters are provided, though inconsistently, with serifs. Words are optionally separated by dots at middle height to the letters. Vowels in initial position are marked, though not consistently, with a dot. Dots also occur above vowels in the medial and final positions, either to mark accent or to highlight the vowel as a syllable (for details, see palaeographic apparatus). Nomina sacra are used according to common rules. Titles are abbreviated thrice through placing the last preserved letter in upper case; by chance, this letter is $\mathrm{T}$ in all three cases.

The person who carved the inscription in the stone made serious mistakes at work, omitting substantial parts of the text, and corrected himself adding the omitted words or phrases on the margins. For a detailed discussion of these phenomena see general commentary.

The inscription remains unpublished. Its discovery was reported by Julie Anderson. ${ }^{3}$ The career of the deceased was discussed briefly by Adam Łajtar and Jacques van der Vliet. ${ }^{4}$

The object can be dated to the ninth century based on archaeological context and palaeography.

$\dagger$

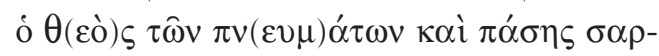

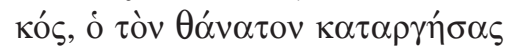

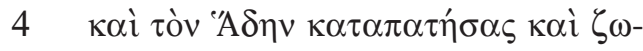

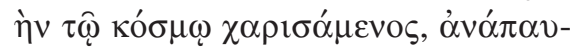

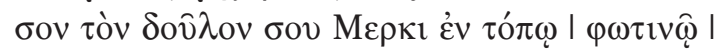

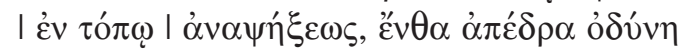

$8 \kappa \alpha i \lambda \lambda v^{\prime} \eta \cdot \kappa \alpha i ̀ ~ \sigma \tau \varepsilon v \alpha \gamma \mu o ́ v \cdot \pi \hat{\alpha} v \delta \varepsilon \dot{\alpha}$ -

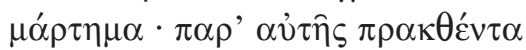

$\langle\tau \grave{\alpha}\rangle \dot{\varepsilon} \kappa o v ́ \sigma 1 \alpha, \tau \grave{\alpha} \alpha \dot{\alpha} \kappa o v ́ \sigma 1 \alpha, \tau \grave{\alpha} \dot{\varepsilon} v \gamma v \omega ́ \sigma \varepsilon[1], \tau \grave{\alpha}$

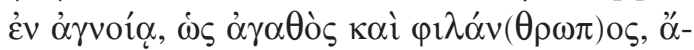

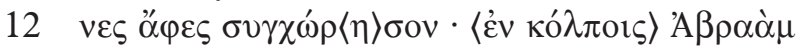

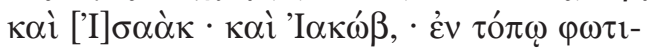

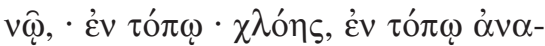

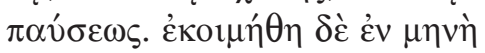

$16 \Theta \hat{\omega} \theta \overline{\kappa \beta} \dot{\varepsilon} \kappa о н \mu \dot{\theta} \theta \eta$. $\tau \grave{\alpha} \delta \dot{\varepsilon}$

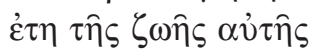

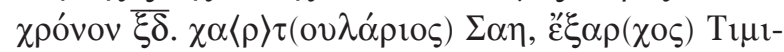

$\kappa \lambda \varepsilon \omega \varsigma \dot{v} \psi \eta\langle\lambda \hat{\eta}\rangle_{\varsigma} \gamma \hat{\eta} . \dagger$

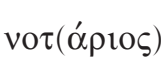

$\mu \iota \zeta \omega \dot{\tau \varepsilon \rho о \varsigma}$

$\pi \rho \omega \tau(0)-$
$\delta o-$
$\mu i ́ \sigma-$
$\tau \imath-$
$\kappa-$
o- $^{-}$
$\varsigma$

3 Anderson 1999: 75.

${ }^{4}$ In: Łajtar 2006: 102-104 (with the focus on the office of chartoularios of Saï); Łajtar 2015: 231-232 (with the focus on the place-name Timikleos); Łajtar, Van der Vliet 2010: no. 20, commentary to lines 10-11 (about the title of notarios). 


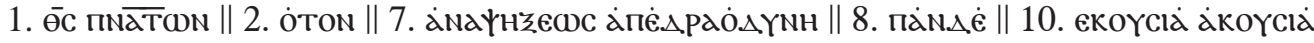

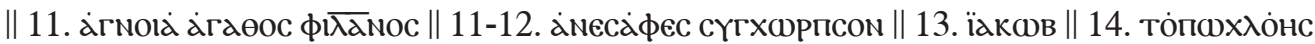

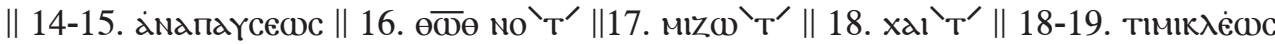

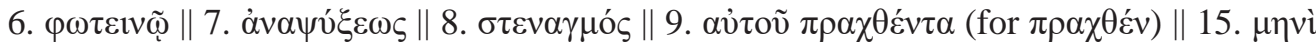

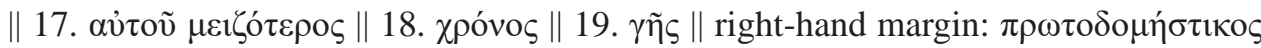

God of spirits and of all flesh, you who have defeated death and trodden down Hades and given life to the world, rest Your servant Merki in a shining place, in a place of refreshment, from which pain and grief and lamentation have fled away. As a good God and loving mankind forgive every sin committed by her (sic!), both conscious and unconscious, (committed) in the state of knowledge and in ignorance, remit and redeem, (in the bosom) of Abraham and Isaac and Jacob, in a shining place, in the place of verdure, in the place of rest. He fell asleep in the month of Thoth (day) 22. And the years of her (sic!) life (were) age 64. (He was) chartoularios of Saï, exarchos of Timikleos, the lofty land, notarios, meizoteros, protodomestikos.

\section{GENERAL COMMENTARY}

The Hambukol epitaph of Merki belongs to a wider group of Nubian Christian funerary inscriptions characterised by a long prayer for the dead beginning with the invocation ó $\theta$ cò $\varsigma$

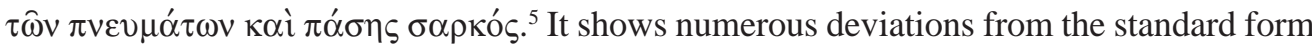
of this prayer as found on Nubian tombstones. The majority of these deviations are due to inadvertence of either the redactor of the inscription or the stonemason (or both of them).

The most substantial of all these changes is a complete remodelling of the second part of the prayer following the words $\pi \hat{\alpha} v \dot{\alpha} \mu \alpha \rho^{\prime} \tau \eta \mu \alpha \pi \alpha \rho$ ' $\alpha \hat{v} \tau o \hat{v} \pi \rho \alpha \chi \theta \dot{\varepsilon} v$. The original

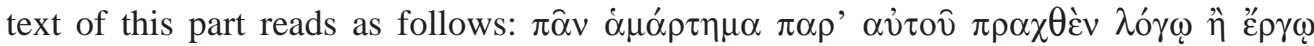

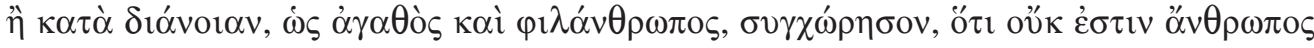

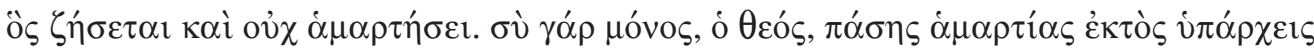

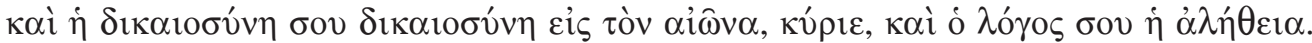

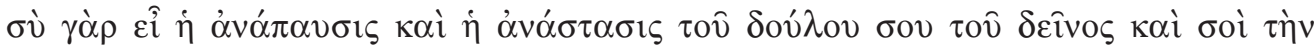

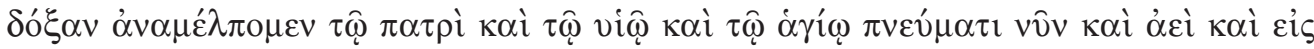

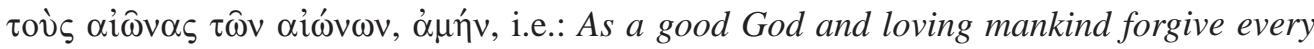
sin committed by him in word or in deed or in thought, for there is not a man who would live and would not sin. For you alone, O God, are without every sin, and your justice is justice forever, $O$ Lord, and your word is truth. For you are the rest and the resurrection of your servant NN and to you we sing glory, Father and Son and Holy Spirit, amen. Of this

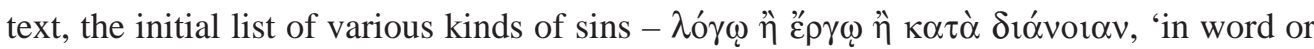

\footnotetext{
${ }^{5}$ For these epitaphs, see most recently: Łajtar 2003: XXI-XXIII. A list of epitaphs (now much outdated) is found in: Łajtar 1996: 101-108. For the prayer itself, its origin, structure, and theological message, see: Brakmann 2006: 303-310.
} 
in deed or in thought' - was substituted, possibly under a liturgical model, by another one,

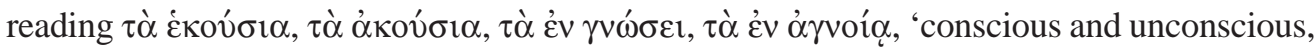
(committed) in the state of knowledge and in ignorance', and the rest, following the request

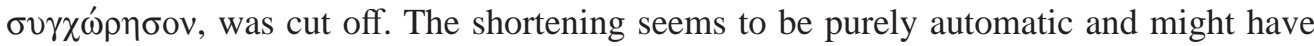
been caused by the lack of space on the stone. Note, however, that the Dongolese epitaph of the priest Stephanos (Istephanou), also called Eiñitta, dating from AD 797, ${ }^{6}$ has the prayer for the dead breaking in exactly the same place, which may suggest that there was a certain tradition, at least in the Dongola area, to abbreviate the prayer with the request

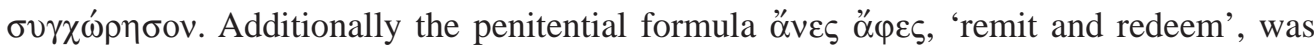

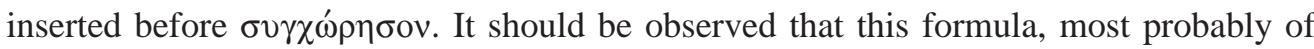
liturgical origin, occurs in exactly this place in several Nubian epitaphs with the prayer

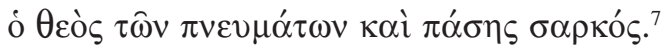

In the first part of the prayer, changes occur in its second half where God is asked to grant various places of rest for the soul of the deceased. The text reads as follows in

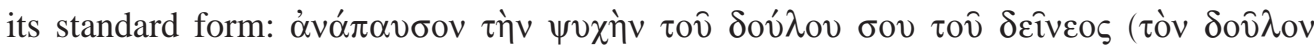

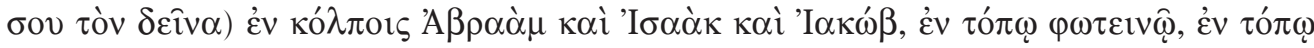

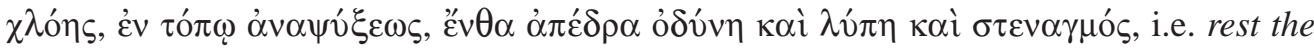
soul of your servant (rest your servant) in the bosom of Abraham and Isaac and Jacob, in a shining place, in a place of verdure, in the place of refreshment, whence pain and

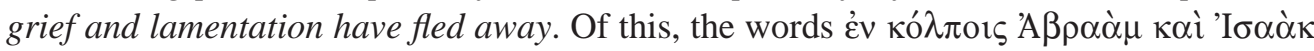

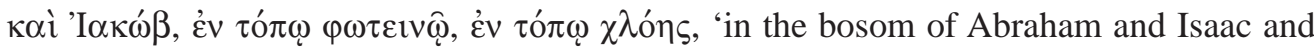
Jacob, in a shining place, in a place of verdure' were omitted. The stonemason was aware of this omission and tried to improve the text in a double way. First he added $\varphi \omega \tau \imath v \hat{\omega}$ (= $\varphi \omega \tau \varepsilon v \nu \omega)$ in the right-hand margin, to the right of line 6, and $\dot{\varepsilon} v \tau$ ó $\pi \omega$ in the left-

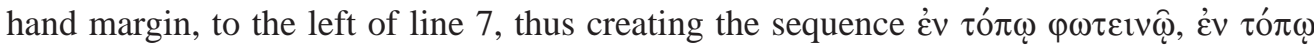
$\dot{\alpha} v \alpha \psi v^{\prime} \xi \varepsilon \omega \varsigma$, 'in a shining place, in a place of refreshment' (the additions are marked by vertical strokes in the edition above). Second he repeated the entire omitted sequence in lines $12-15$ in a fully arbitrary way, without any syntactical and semantic connection with the neighbouring phrases. One can suppose that he introduced the omitted text in this very place because he was exactly there during the work when he stated that he made the omission. By the occasion of this self-correction, the words $\dot{\varepsilon} v$ kó $\lambda \pi$ or $\varsigma$ had fallen out, which causes the names of the patriarchs to be deprived of a regens. Interestingly, the text

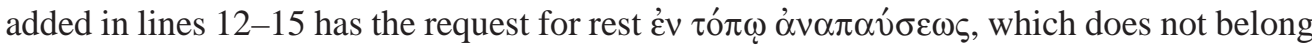

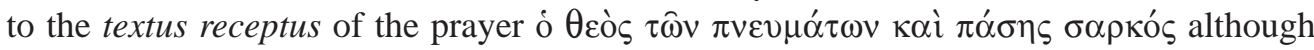
it sometime occurs in place of $\dot{\varepsilon} v \tau o ́ \pi \omega \dot{\alpha} v \alpha \psi v \dot{\xi} \varepsilon \omega \varsigma$ in Nubian epitaphs with the prayer in question. ${ }^{8}$ One can summarise the above observations as follows: initially the stonemason tried to correct his mistake in a restricted way using the free space on both sides of the main text, but then decided to introduce a serious correction for which he had to interrupt

\footnotetext{
${ }^{6}$ Łajtar, Twardecki 2003: no. 110.

7 Cf. Łajtar 2003: no. 3, commentary to line 9. Generally for the formula, see: Wade 2005.

${ }^{8}$ Cf. Łajtar 2003: no. 9, commentary to line 9.
} 
the main text. As a result of these omissions and self-corrections, he produced a text which is redundant in at least one, and, if we eliminate the opposition between $\dot{\alpha} v \alpha \psi v \dot{\xi} \xi \omega \varsigma$ and

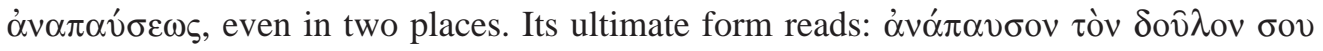

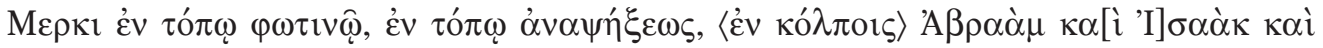

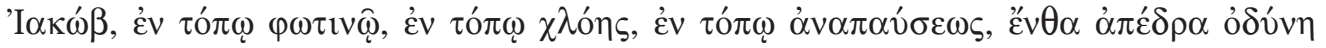

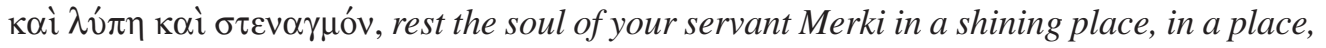
of refreshment, in the bosom of Abraham and Isaac and Jacob, in a shining place in a place of verdure, in a place of rest, from which pain and grief and lamentation have fled away.

The prayer for the deceased is followed by information about the date of his death and the length of his life. The former is introduced by the habitual غ่ко $\mu \eta \dot{\theta \eta}$, here doubled most probably as the result of a conflation (see line commentary), the latter - with the

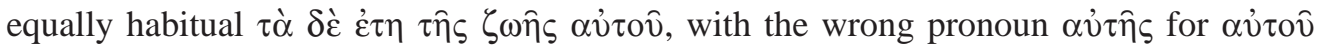
(see line commentary).

After the information about the date of death and the length of life, the text continues with the description of the career of the deceased man. It assumes the form of an asyndeton deprived of an introductory formula. An asyndetic list of titles is common as a description of the deceased's career in Nubian epitaphs. One can cite here such examples as the epitaph of the priest Stephanos (Istephanou) from Dongola (died AD 797), ${ }^{9}$ the epitaph of Staurophoros from Debeira (died AD 1069),${ }^{10}$ the epitaph of Marianou, bishop of Phrim (died AD 1132), ${ }^{11}$ and many more. However, the placement of the titles' list in Merki's epitaph and the lack of an introductory formula are rather exceptional. In the epitaphs with

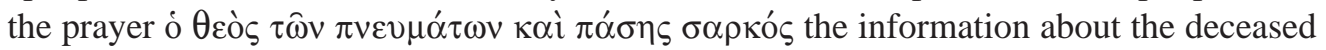

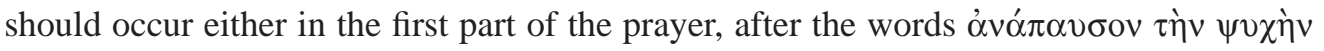

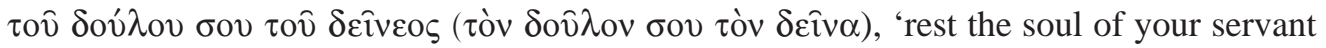

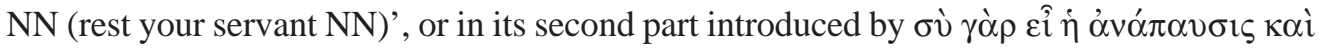

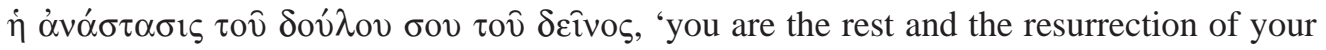
servant NN'. The remodelling of the second part of the prayer, which led to the elimination of the latter expression, might have been the reason why the redactor of the present epitaph (followed by the stonemason) chose another, somewhat artificial, solution. Another possibility is that he added the description of Merki's career as an afterthought. If this second possibility is correct, we would have further proof of his inattention at work.

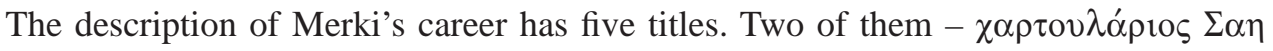
and ${ }^{\prime} \xi \alpha \rho \chi 0 \varsigma$ T $1 \mu \iota \kappa \lambda \varepsilon \omega \varsigma \dot{v} \psi \eta \lambda \hat{\eta} \varsigma \gamma \eta \hat{\eta} \varsigma$ - belong to the original body of the text, closed with a cross at the end of line 19. The remaining three must be considered as later additions. Two of these additions - vo $\tau\left(\dot{\alpha} \rho \iota_{\varsigma}\right)$ and $\mu 1 \zeta \omega ́ \tau \varepsilon \rho o \varsigma$ - were recorded in free spaces towards

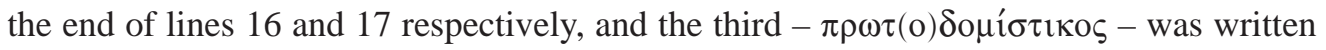
from top to bottom in the right-hand margin. This supposed sequence of writing the titles is strange as it does not correspond with the importance of the titles, neither in ascending

\footnotetext{
9 Łajtar, Twardecki 2003: no. 110.

10 Hägg 1982: 57.

11 Łajtar, Van der Vliet 2010: no. 21.
} 
nor descending order, which means that it does not mirror the chronological cursus of Merki. Obviously the redactor of the epitaph (followed by the stonemason) was again not very attentive at work and listed the titles without order, or with little order, as they came to his mind. When arranged according to the importance of the titles in ascending order,

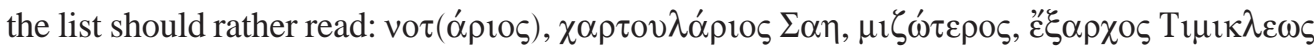

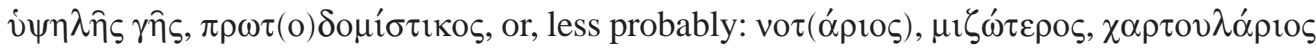

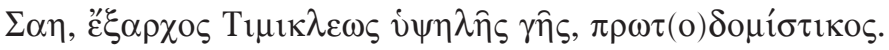

The career of Merki as reconstructed above is remarkable. It started with two offices connected with drafting and keeping documents (notarios, chartoularios of Saii). In this context it is worth stressing that Merki obviously was not an ecclesiastic, which means that literacy was not restricted to the men of the Church and was accessible also for laity in Christian Nubia. After that, Merki continued his career with two posts in the territorial administration (meizoteros, exarch of Timikleos), whereby the second of these posts was connected with the capital of the Kingdom of Makuria. He ended up with the office of protodomestikos, thus becoming a person in the closest entourage of the King, his deputy for fiscal and economic matters in the entire Kingdom of Makuria. One wonders how to interpret the remarkable promotion of Merki from the low office of notarios to the very high office of protodomestikos. Two possibilities seem to come in mind. Either the Kingdom of Makuria had state structures loose enough and the enough social mobility to allow the making of splendid careers by ambitious and well-educated men even if they did not belong to the uppermost strata of the society, or 'aristocrats', similarly as members of the ordo senatorius in ancient Rome, had to follow a strict cursus honorum before entering into the most elevated posts in the administration of the state. At the moment we have no data for solving the question but future finds of a textual nature may cast a light on it.

\section{LINE COMMENTARY}

6. The personal name Merki (мєркı, also spelled мєркн) is well attested in Christian Nubia. In addition to the person commemorated by this epitaph the following bearers of this name are known: мєркн прє(свүтєрос) mentioned in a graffito on the rocks near Ashkeit in the area of the second cataract (date unknown); ${ }^{12}$ меркı, son of мартосоүгоү $\lambda d$, mentioned in a graffito on the rocks of the so-called Gebel Maktub near Qasr Ibrim (tenth/eleventh

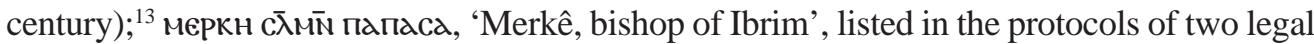
documents, one found in Qasr Ibrim (AD 1463), ${ }^{14}$ the other in Gebel Adda (date unknown); ${ }^{15}$ мєркн, mentioned as the author of a literary(?) text from Qasr Ibrim (date unknown); ${ }^{16}$ мєркн прє(свүтєрос), addressee of a letter found in Qasr Ibrim (date unknown). ${ }^{17}$ мєркı is probably

\footnotetext{
12 Łajtar, Van der Vliet 1998: 51, no. 13 (= Van der Vliet 2018: 359-360, no. 13).

13 Unpublished.

14 Ruffini 2014: no. 63, 6.

15 Unpublished; preliminarily, see: Millet 1967: 62.

16 Ruffini 2014: no. 88, r 1.

17 Ruffini 2014: no. 110, v 12.
} 
a hypocoristic of Meркоиิpros provided with the formant /-i/ frequently occurring at the end of Nubian substantives including names.

8. The spelling стелагмом instead of стелагмос has probably nothing to do with morphology or syntax (accusative for nominative) but is purely phonological: the loss of /s/ in the final position with the simultaneous addition of $/ \mathrm{n} / .^{18}$ Without being frequent, the spelling стелагмом (стелагмам) occurs in Nubian epitaphs with the prayer ó $\theta \varepsilon$ ò

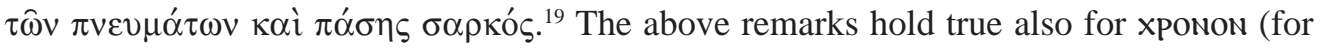

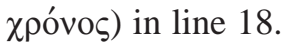

8-11. The direct object in singular ( $\pi \hat{\alpha} v \dot{\alpha} \mu \alpha \rho \rho \eta \mu \alpha)$ is connected with the attribute in

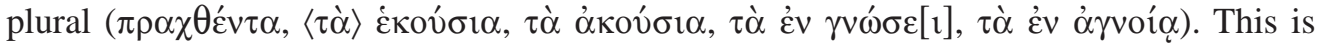
probably due to the $-\alpha$ ending of the word $\alpha \mu \alpha \rho \tau \eta \mu \alpha$, which makes the impression for an unqualified person of being plural. The correct reading should be: $\pi \hat{\alpha} \nu \dot{\alpha} \mu \alpha \dot{\rho} \tau \eta \mu \alpha \pi \alpha \rho$ '

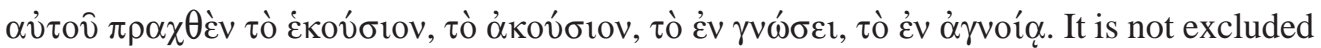
that the redactor of the inscription wanted to put all these elements in the plural: $\pi \alpha{ }^{\prime} \tau \alpha$

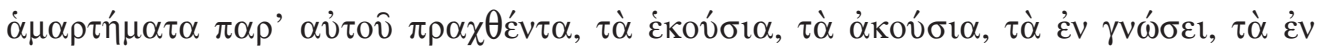
$\dot{\alpha} \gamma$ voí $\alpha$. Against this supposition is that the object is singular in the textus receptus of the

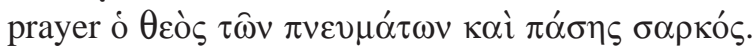

9. $\pi \alpha \rho$ ' $\alpha \dot{\tau} \hat{\eta} \varsigma$ instead of $\pi \alpha \rho ' \alpha \hat{\tau} \tau$ ov is strange. It is known that Nubian epitaphs for women frequently contain masculine forms $\delta$ ov̂ $\lambda$ o $\varsigma$ for $\delta$ ov́ $\lambda \eta$ and $\alpha \hat{v} \tau$ ó $\varsigma$ for $\alpha \hat{\tau} \tau \eta^{20}$ Their occurrence is attributed to the fossilisation of some expressions like $\alpha v \alpha \dot{\pi} \alpha \omega \sigma o v$ iòv $\delta$ ov $\lambda$ ov and $\pi \hat{\alpha} \nu \dot{\alpha} \mu \alpha \rho^{\prime} \tau \eta \mu \alpha \pi \alpha \rho^{\prime} \alpha \hat{v} \tau o \hat{v} \pi \rho \alpha \chi \theta \dot{\varepsilon} v$, and to the weak sense of grammatical gender among the Nubian speakers whose native tongue did not possess this grammatical category. The latter explanation may hold true also for our case, where the feminine form is used for a man. Another instance of $\alpha \dot{v} \tau \hat{\eta} \varsigma$ used instead of $\alpha \dot{v} \tau o \hat{v}$ occurs in line 17, but the latter occurrence should probably be interpreted differently.

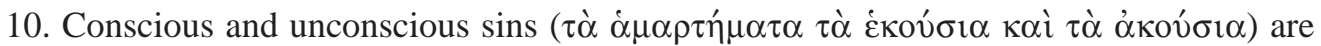
similarly referred to in the prayer for the dead contained in the epitaph of an unknown person found in Khandak, several kilometres to the north of Hambukol: $\pi \alpha \rho \rho \rho \hat{\omega} v \alpha \hat{\tau} \tau($ ) $\tau \grave{\alpha} \dot{\alpha} \mu \alpha \rho \tau \eta \dot{\eta} \mu \alpha \tau(\alpha) \pi \dot{\alpha} v \tau(\alpha) \tau \grave{\alpha} \dot{\varepsilon} \kappa o v ́ \sigma 1 \alpha[(\kappa \alpha \grave{i}) \dot{\alpha} \kappa o v ́ \sigma \iota \alpha] .{ }^{21}$ Sins committed in the state of knowledge and in ignorance are not mentioned in Greek epitaphs from Nubia but are pointed out in the Old Nubian part of the epitaph of the Nubian King Georgios, who died in $\mathrm{AD} 1157$ in Wadi Natroun in Lower Egypt and was buried there: там гапєгоүком

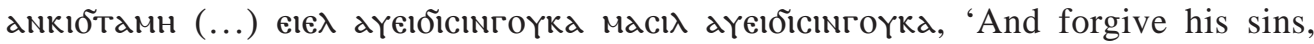

\footnotetext{
18 Generally for this phenomenon, see: Gignac 1976: 131-132.

19 Examples collected in: Łajtar 2003: no. 3, commentary to line 8.

20 See, for example: Łajtar 2003: no. 7, commentary to line 13.

${ }^{21}$ Łajtar 2003: no. 16.
} 
(...) that he committed knowing (and) not knowing' ${ }^{22}$ Outside of Nubia, they are referred

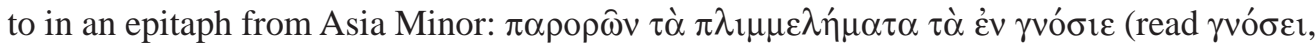

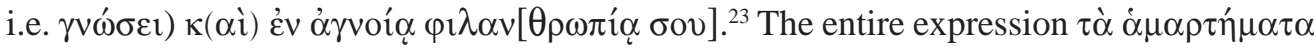

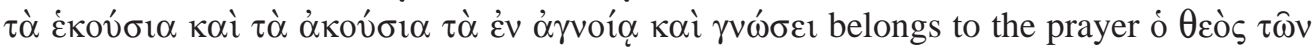

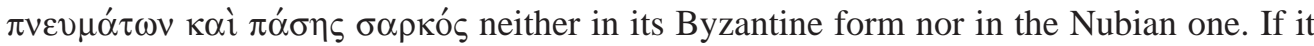
occurs in the epitaph of Merki, it was introduced either by the redactor of this epitaph or by someone else on an earlier stage of the text transmission. In the latter case, we would

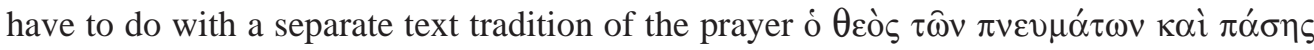
$\sigma \alpha \rho \kappa o ́ \varsigma$ in this very place where the redactor of the Merki's epitaph was active or where he was educated. The source of borrowing for this expression most probably was of liturgical character. This might have been a prayer for the dead from the funerary liturgy of

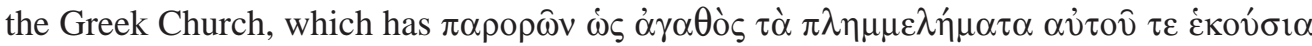

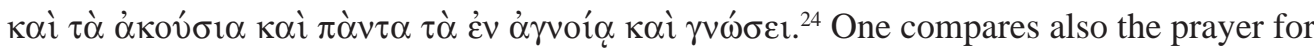

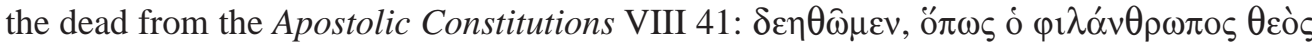

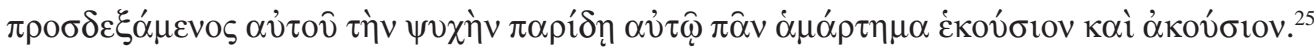

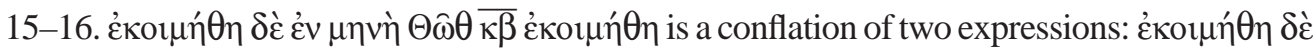
$\dot{\varepsilon} v \mu \eta v \grave{\eta} \Theta \hat{\omega} \theta \overline{\kappa \beta}$ and $\dot{\varepsilon} v \delta \grave{\varepsilon} \mu \eta v \grave{\eta} \Theta \hat{\omega} \theta \overline{\kappa \beta} \dot{\varepsilon} \kappa o u \mu \eta \dot{\eta} \theta \eta$. Actually, one of the two $\dot{\varepsilon} \kappa o u \mu \eta \dot{\theta} \theta \eta$ should be eliminated.

The name of the month Thoth is recorded with a dash over it $(\theta \bar{\Theta} \theta)$. Marking the month names with horizontal dashes is a widespread practice in Christian Nubian literacy. ${ }^{26}$ The reason for this practice is not clear. Perhaps Nubian writers wanted to underscore in this way that names of months of the Egyptian calendar do not undergo the rules of Greek declension.

17. $\alpha \dot{v} \tau \hat{\eta} \varsigma$ (instead of $\alpha \dot{v} \tau 0 \hat{v}$ ) is probably due to the influence of the neighbouring $\zeta \omega \eta \bar{\varsigma}$.

18. For the spelling xponon (for $\chi \rho o ́ v o \varsigma$ ), see commentary to line 8 where a similar case

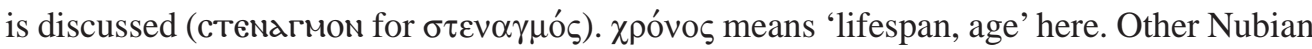
epitaphs use $\dot{\eta} \mu \varepsilon^{\prime} \alpha \alpha$ in analogical context. ${ }^{27}$

18-19 + additions on the right-hand margin. The title of chartoularios, literally 'the one who is dealing with chartai', i.e. sheets of writing material, is attested several times in Christian Nubia, ${ }^{28}$ but it is only here that it is modified by a place name. Most probably,

22 Van Gerven Oei 2011. The phrase in question is found in line 12.

23 Sterrett 1888: 314.

24 Goar 1730: 426.

25 Les constitutions apostoliques 3.

${ }^{26}$ For a collection of evidence, see: Ochała 2011: 225-237, 249-250. The practice is attested in relation to the following month names: Thoth, Hathyr, Khoiak, Tybi, Mekheir, Pakhon, and Mesore.

${ }^{27}$ For the meaning of the word $\dot{\eta} \mu \varepsilon \rho \alpha$ in Greek Christian epitaphs from Nubia, see: Hägg 1982: 59.

${ }^{28}$ For a collection of evidence and a discussion, see: Łajtar 2006: 102-104, where this inscription is also cited. 
chartoularios of Saï was the head of an office located in this very place where documents were drawn and kept. This was either a town-office or an office connected with a larger administrative unit within the Kingdom of Makuria, of which Saï was capital.

The title of exarchos is not very common in Christian Nubian sources. ${ }^{29}$ Nubian exarchoi were probably civilian officials, governors of certain areas (districts), important from the point of view of the functioning of the Kingdom of Makuria (earlier also Kingdom of Nobadia). The comparison with the Eastern Roman exarchoi suggests that their authority was of both a civilian and military nature. It has been suggested in the earlier scholarship that Nubian exarchoi could have been Church officials. ${ }^{30}$ The purely civilian career of Merki shows that this cannot be true, at least for him.

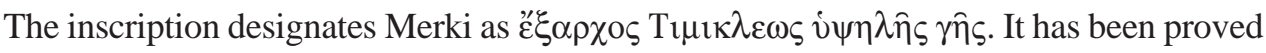
recently that Timikleos is the name for Dongola, the capital of Makuria, used in Greek and Coptic sources. ${ }^{31}$ The designation $\dot{v} \psi \eta \lambda \grave{\eta} \gamma \hat{\eta}$, 'lofty land', for Dongola appears only here and its origins are unknown. It may refer to either the particular location of the citadel of Dongola on a rocky outcrop in an otherwise plain neighbourhood or the prominent role Dongola played within the Kingdom of Makuria as the royal capital. A commentary is necessary for the spelling $\Upsilon^{4} \mathrm{Hc}$ occurring on the stone. I have edited the place as we were dealing with the omission of a syllable ( $\dot{v} \psi \eta\langle\lambda \hat{\eta}\rangle \varsigma)$. Such an omission is explicable as a kind of haplography facilitated by the fact that the omitted syllable and the preceding one have

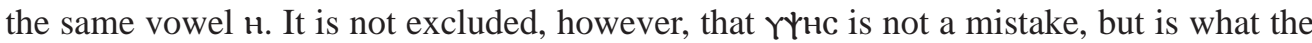
redactor of the inscription exactly wanted in this place. He might have felt that the adjective

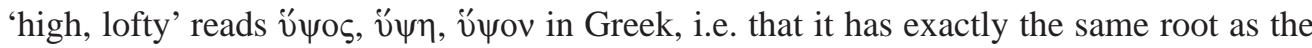

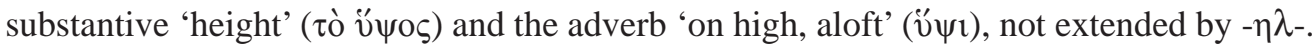

It is interesting to observe that Dongola was the centre of an exarchate. This is surely connected with its capital functions within the Kingdom of Makuria. A smooth and undisturbed functioning of the royal court and the central administration obviously required a special organisational frame, uniting, as it seems, civilian and military authority in one hand. The extension of this exarchate is difficult to estimate. It could have encompassed the town of Dongola itself and its immediate hinterland including the fertile Letti Basin, which must have been the main source of supply for the capital.

The title of notarios is attested several times with relation to Christian Nubia. ${ }^{32}$ Greek

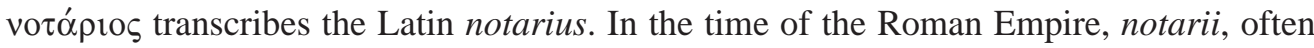
recruited from among the imperial freedmen, were primarily stenographers who recorded

${ }^{29}$ For a collection of evidence and a discussion, see: Łajtar, Van der Vliet 2010: no. 43, commentary to line 5, where this inscription is also cited. To the Nubian attestations of exarchoi collected and discussed there one can add three further examples in Coptic legal documents from Qasr Ibrim datable to the tenth-eleventh century (unpublished; preliminarily, see: Hagen 2009: 117). These are: exarch of Talmis, exarch of the district of Kouttouke, and exarch of Adom [ - - - ] (names of holders not given in Hagen's preliminary presentation).

30 See discussion in: Hägg 1990: 160-161.

31 Łajtar 2015.

32 For a list of attestations (including, among other, the inscription published here) and a discussion, see: Łajtar, Van der Vliet 2010: no. 20, commentary to line 10. 
the minutes of important meetings. ${ }^{33}$ Later, in the time of the Eastern Roman Empire, they were known as scribes and secretaries serving in various government departments like genikon, vestiarion, dromos, etc. It is undoubtedly in this later meaning that the term notarios was used in Christian Nubia. One can suppose that Nubian notarioi were clerks employed in the bureaus of higher officials and drafting documents for them.

As far as Christian Nubia is concerned, the title of meizoteros has been attested ten times in addition to this inscription. ${ }^{34}$ The list of attestations is as follows:

(1) Paulos meizoteros commemorated by a Coptic epitaph of Lower Nubian provenance; date unknown; ${ }^{35}$

(2) Epephanios (i.e. Epiphanios) meizoteros commemorated by a Greek epitaph of Lower Nubian provenance; date unknown; ${ }^{36}$

(3) Ang( )phorou mizoteros commemorated by an epitaph in Greek found in Qasr Ibrim; date unknown; ${ }^{37}$

(4) Starophoros, meiz ( ), nauarches of Nobades and nau( ) of Seven Lands, commemorated by a Greek epitaph found at Debeira; AD 1069; note that both the reading meiz(oteros) and meiz(on) is possible in this case; ${ }^{38}$

(5) Simon, meizo ( ) of Nobadia, mentioned in the protocol of a legal document in Coptic; Lower Nubia; possibly second half of the eighth century; ${ }^{39}$

(6) Joseph, meizo( ) of Nobadia, listed in the protocol of a legal document in Coptic; Lower Nubia; possibly beginning of the ninth century; ${ }^{40}$

(7) Abraam, meizoteros of the king, listed in the protocol of a legal document in Coptic dating from AD 925 found in Qasr Ibrim (line 9);41

(8) Georgios, eparch of Nobadia, meizoteros of the protoeparch, listed in the protocol of the same document (lines 9-10);

(9) meizoteros (and) domestikos (name not preserved) mentioned in the protocol of a legal document of AD 1071/1072 found in Qasr Ibrim; ${ }^{42}$ note that the translation is uncertain; it can also be meizoteros (of the) domestikos;

33 Cf. Teitler 1985.

${ }^{34}$ In the following discussion of the title meizoteros I do not make distinction between meizoteros and meizon. The latter has not been attested indisputably in Christian Nubia so far (see remarks to nos [4], [5], [6], [7], and [10] in the list) although it is well known elsewhere. I also do not take into consideration the titles of protomeizoteros and archimeizoteros as they refer to officials of a different grade than meizoteros.

35 Van der Vliet 2002: 185-191 (= Van der Vliet 2018: 284-287).

36 Richter 1999: 296-297.

37 Łajtar, Van der Vliet 2010: no. 56.

38 Hägg 1982: 56-59.

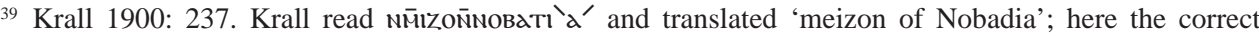

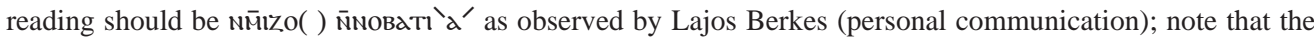

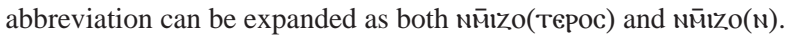

40 Krall 1900: 239. Krall read nmïzon тnовatı and translated 'meizon of Nobadia'; here the correct reading should be nмї̈о( ) мтмоватld as observed by Lajos Berkes (personal communication); note that the

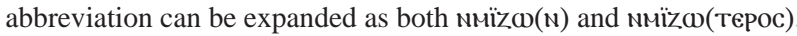

41 Unpublished; quoted after a hand-out distributed by Jack M. Plumley during one of his lectures.

42 Plumley 1981: 7-8, line 8. 
(10) Apapa, deacon of the meiz( ) of Faras, sender of a letter to Ioannes, a bishop; date unknown, but not earlier than twelfth century; ${ }^{43}$ note that the translation of the information about the sender is uncertain; it can also be: 'Apapa, deacon (and) meiz( ) of Faras'; note further that both the reading meiz(oteros) and meiz(on) is possible.

Gerald Michael Browne suggested that Greek (and Coptic) meizoteros, literally 'the

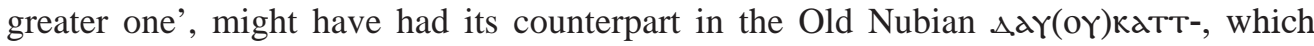

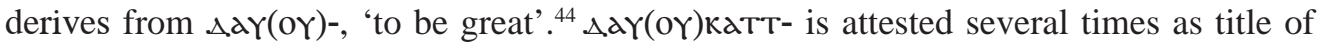
officials in the protocols of Old Nubian documents from Qasr Ibrim from the twelfth-thirteenth century. It may occur as a bare title ${ }^{45}$ or in connection with a place-name, including

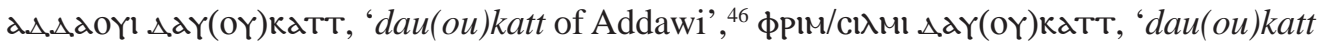

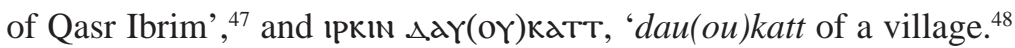

The title of meizoteros is rather vague. In the Eastern Roman Empire it could have been used to designate: (1) a person employed on private title by a particular (a kind of majordomo or steward); (2) a functionary placed under the orders of another official, both civilian and ecclesiastic; (3) an official of a village, head of a village or president of the village's council. ${ }^{49}$ The same ambiguity in the use of the title is observable in Nubia. Abraam and Georgios, numbers (7) and (8) in the list above, were functionaries attached, respectively, to the king and the protoeparch, Simon and Joseph, (5) and (6) in the list, must have been officials on a provincial level, whereas meizoteros of Faras (10), dau(ou)katt of Addawi, dau(ou)katt of Qasr Ibrim, and the dau(ou)katt of a village - officials on the town/village level. As village officials, Eastern Roman meizoteroi had competences in administering the finance and the justice including making arbitration and presiding over courts. Similar competences can tentatively be ascribed to Nubian meizoteroi/dau(ou)katt. It is interesting to observe that the term dau(ou)katt persisted the fall of the Kingdom of Makuria and has been used until present by the inhabitants of the Mahas region in the form dawokati as a designation for the head of a lineage. ${ }^{50}$ The dawokati is elected among old and knowledgeable men of the lineage. He is entrusted to run the affairs of the lineage effectively, to represent the lineage members in front of authorities whenever or wherever need arises, and to regulate the affairs of the lineage with other neighbouring lineages. ${ }^{51}$ The difference between the present-day dawokati and the Nubian meizoteroi/dau(ou)katt is that the latter were most probably state officials whereas the former are representatives of the population but their sphere of activity may not differ very much from each other.

43 Ruffini 2014: no. 89, v 6.

44 Browne 1996a: 130; see also: Browne 1996b: 37.

45 Browne 1991: nos 31, 11; 33, 6; 36, i 11; 39, 27; 40, 19; Ruffini 2014: 71, ro 23; 101, ro 8; 114, ro $16-17$.

46 Browne 1991: nos 30, 11; 34, 12-13; 36, i 7; Ruffini 2014: 67, 6; 69, 5.

47 Browne 1991: nos 34, 33-34; 37, 26; 38, 11; 40, 9; Ruffini 2014: 98, vº 6.

48 Browne 1991: no. 34, 25.

49 For the meaning of the title of meizoteros with the focus on the Late Roman and Early Arab Egypt, see: Rouillard 1928: 69-71; Berkes 2017: 88-121.

50 Cf. Ali Osman 1982: 190.

51 Ali Osman 1982: 190. 
Due to the lack of a closer description it is impossible to decide what was the character of the Merki's office of meizoteros. He could have been both a village/town official and a subaltern functionary acting under another official, although the first possibility seems more probable to me.

The present inscription yields the first epigraphic attestation of the title of protodomestikos in Christian Nubia. Thus far, this title was known only through the protocols of legal documents on leather. All these documents originate from Lower Nubia and are in Coptic. Two documents drafted apparently in Mohondi (Ikhmindi) and now kept in Graeco-Roman Museum in Alexandria mention a protodomestikos Ioannes active under an otherwise unknown king Chael (probably second half of the eighth century). In the first of these documents he is designated as 'protodomestikos of the palace' (про ' $\mathrm{T}^{\prime} \Delta$ Ммєс ' $\mathrm{T}^{\prime}$

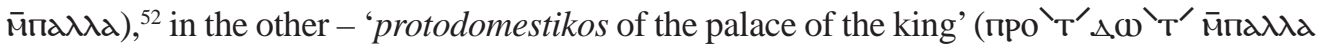

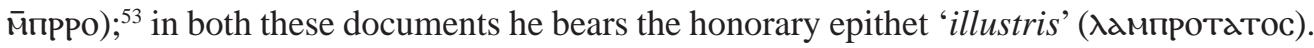
Two sales drafted within the bishopric of Kourte and now kept in the British Museum ${ }^{54}$ let us know a certain Georgios who, at the same time, held as many as three offices, namely protoeparchos, protodomestikos and protomeizoteros. The documents are dated to the time of a king with the name Ioannes (possibly first quarter of the ninth century). Thanks to a Qasr Ibrim document of AD 925 containing an agreement about a slave ownership we learn that the then reigning king Zacharias, son of Georgios, held also the offices of protoeparchos and protodomestikos. ${ }^{55}$ The same document informs that a certain Koudimpr[ . ] was architriklinaris of the King, triklinaris of the protodomestikos, and eparch of Nobadia. Finally, a fragmentary document of AD 1071/1072 found in Qasr Ibrim lists among the highest officials of the Kingdom of Makuria 'protodomestikos of the palace' (прш ' $\mathrm{T}^{\prime} \Delta \omega \mathbf{\omega}^{\prime} \mathrm{M}^{\prime}$

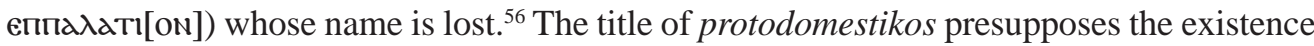
of the lower-rank title of domestikos. The latter is well attested in both the Greek form (used also in Coptic) and its Nubian counterpart samet/samat. In the large majority of cases, domestikos/samet is qualified as that of Pachoras/Faras; ${ }^{57}$ the holders of this title were often eparchs of Nobadia. There is also a single attestation of a samet of Tapha. ${ }^{58}$ The office of samata was known in the Kingdom of Kokka that arose in the area to the north of the third cataract after the fall of Makuria. ${ }^{59}$ The samata of Kokka was the head of a saqia, i.e. an areal watered by one water-wheel, and was responsible for collecting tax in kind, especially in dates. The word persisted (as samad/samed) until quite recently in some parts of the Dongola area with exactly the same meaning as in the Kingdom

52 Krall 1900: 236-237.

53 Krall 1900: 238-239.

54 Crum 1905: nos 449-450.

55 The document remains unpublished. I am quoting it here after a hand-out distributed by Plumley during one of his lectures.

56 Plumley 1981: 5-8, line 5.

57 The attestations are too numerous to be listed here; for a complete list, see: Medieval Nubia: Offices and titles, s.v. domestikos.

58 Browne 1991: no. 38, line 12.

${ }^{59}$ For the organisation and functioning of the Kingdom of Kokka, see: Ali Osman 1982. 
of Kokka. ${ }^{60}$ Assuming that the administration of the Kingdom of Kokka followed that of its predecessor, the Kingdom of Makuria, one can suppose that the Makurian domestikos /samet was a royal official responsible for agriculture and fiscal matters in a given area - a village, a town or a larger administrative unit. Consequently protodomestikos must have been an official of the central administration who organised and watched over the work of domestikoi in the entire Kingdom of Makuria. His office was of the same grade as that of protoeparchos and protomeizoteros, no wonder then that the three could have been concentrated in one hand. Moreover they could have been fulfilled by King, which testifies to their importance from the point of view of the Kingdom's functioning.

\section{Acknowledgments}

I would like to thank Krzysztof Grzymski, curator in the Department of World Cultures of the Royal Ontario Museum and director of the ROM archaeological mission to Hambukol, for inviting me to publish this interesting object and arranging my study trip to Toronto. I also thank Grzegorz Ochała for reading through an earlier version of this paper and commenting upon it and to Giovanni Ruffini for correcting the English of the paper.

\section{References}

Ali Osman 1982: The post-medieval Kingdom of Kokka: A means for a better understanding of the administration of the medieval Kingdom of Dongola, [in:] Plumley, J.M. (Ed.), Nubian Studies: Proceedings of the Symposium for Nubian Studies, Selwyn College, Cambridge, 1978, Warminster, 185-197

Anderson, J. 1999: Monastic Lifestyles of the Nubian Desert: Seeking the Mysterious Monks of Makuria, SudNub 3, 71-83

Armbruster, Ch.H. 1965: Dongolese Nubian: A Lexicon, Cambridge

Berkes, L. 2017: Dorfverwaltung und Dorfgemeinschaft in Ägypten von Diokletian zu den Abbasiden, Philippika 104, Wiesbaden

Brakmann, H. 2006: Defunctus adhuc loquitur. Gottesdienst und Gebetsliteratur der untergegangenen Kirche in Nubien, Archiv für Liturgiewissenschaft 48, 288-333

Browne, G.M. 1991: Old Nubian Texts from Qașr Ibrīm III, Texts from Excavations 12, London

Browne, G.M. 1996a: Notes on Old Nubian texts from Qașr Ibrīm III, BSF 6, 129-132

Browne, G.M. 1996b: Old Nubian Dictionary, CSCO 556, Subsidia 90, Leuven

Crum, W.E. 1905: Catalogue of the Coptic Manuscripts in the British Museum, London

Gerven Oei, V. van 2011: The Old Nubian memorial for King George, [in:] Łajtar, A., Vliet, J. van der (Eds), Nubian Voices. Studies in Christian Nubian Culture, JJPSuppl. XV, Warsaw, 225-262

Gignac, F.Th. 1976: A Grammar of the Greek Papyri of the Roman and Byzantine Periods 1: Phonology, TDSA 55, Milan

${ }^{60}$ Nicholls 1918: 21; Tothill 1948: 952; and see further: Armbruster 1965: 172, s.v. sámed. 
Goar, J. 1730: EYХОАОГION sive rituale Graecorum, Venice (reprint: Graz 1960) Grzymski, K., Anderson, J.R. with contributions by Żurawski, B., Edwards, D., Mason, R., Phillips, J., Vogelsang-Eastwood, G. 2001: Hambukol Excavations 1986-1989, Society for the Study of Egyptian Antiquities Publications XVI, Canadian Expedition to Nubia I, Mississauga

Hagen, J. 2009: Districts, towns and other locations of medieval Nubia and Egypt, mentioned in the Coptic and Old Nubian texts from Qasr Ibrim, SudNub 13, 114-119

Hägg, T. 1982: Two Christian Epitaphs in Greek of the Euchologion Mega Type, [in:] SäveSöderbergh, T. (Ed.), Late Nubian Cemeteries, SJE VI, Solna, 55-62

Hägg, T. 1990: Titles and Honorific Epithets in Nubian Greek Texts, SymbOsl 65, 147-177 Krall, J. 1900: Ein neuer nubischer König, WZKM 14, 233-242

Les constitutions apostoliques 3: Les constitutions apostoliques 3, Ed. and transl. Metzger, M., SourcChr 336, Paris 1987

Łajtar, A. 1996: Varia Nubica IV: Das älteste nubische Epitaph mit dem Gebet vom sogenannten Typus Euchologion Mega?, ZPE 113, 101-108

Łajtar, A. 2003: Catalogue of the Greek Inscriptions in the Sudan National Museum at Khartoum (I. Khartoum Greek), OLA 122, Leuven-Paris-Dudley MA

Łajtar, A. 2006: Christian Saï in written records (inscriptions and manuscripts), JJP XXXVI, 91-104

Łajtar, A. 2015: The mystery of Timikleos solved!, [in:] Łajtar, A., Ochała, G., Vliet, J. van der (Eds), Nubian Voices II. New Texts and Studies on Christian Nubian Culture, JJP-Suppl. XXVII, Warsaw, 231-243

Łajtar, A., Twardecki, A. 2003: Catalogue des inscriptions grecques du Musée National de Varsovie, JJP-Suppl. II, Warsaw

Łajtar, A., Vliet, J. van der 1998: Rich ladies of Meinarti and their churches. With an appended list of sources from Christian Nubia containing the expression "having the Church of so-and-so", JJP XXVIII, 35-53

Łajtar, A., Vliet, J. van der 2010: Qasr Ibrim. The Greek and Coptic Inscriptions, JJPSuppl. XIII, Warsaw

Medieval Nubia: http://www.medievalnubia.info (accessed December, 2018)

Millet, N.B. 1967: Gebel Adda Preliminary Report, 1965-66, JARCE 6, 53-63

Nicholls, W. 1918: The saqia in Dongola province, SNRec 1, 21-24

Ochała 2011: Chronological Systems of Christian Nubia, JJP-Suppl. XVI, Warsaw

Plumley, J.M. 1981: A Coptic Precursor of a Medieval Nubian Protocol, Sudan Texts Bulletin 3, 5-8

Richter, T.S. 1999: Die neun Stelen Ägyptisches Museum der Universität Leipzig Inv.Nr. 680-688 mit der Herkunftsangabe Qasr Ibrim, [in:] Emmel, S., Krause, M., Richter, S.G., Schaten, S. (Eds), Ägypten und Nubien in spätantiker und christlicher Zeit. Akten des 6. Internationalen Koptologenkongresses, Münster, 20.-26. Juli 1996, vol. 2, Schrifttum, Sprache und Gedankenwelt, SKCO 6, Wiesbaden, 295-304

Rouillard, G. 1928: L’administration civile de l’Égypte byzantine, Paris 
Ruffini, G.R. 2014: The Bishop, the Eparch, and the King. Old Nubian Texts from Qasr Ibrim (P. QI IV), JJP-Suppl. XXII, Warsaw

Sterrett, J.R.S. 1888: The Wolfe Expedition to Asia Minor, PASA 3, Boston

Teitler, H.C. 1985: Notarii and Exceptores. An Inquiry into Role and Significance of Shorthand Writers in the Imperial and Ecclesiastical Bureaucracy of the Roman Empire (from the Early Principate to c. 450 A.D.), Dutch Monographs on Ancient History and Archaeology 1, Amsterdam

Tothill, J.D. 1948: Glossary of Arabic and vernacular words, [in:] Tothill, J.D. (Ed.), Agriculture in the Sudan. Being a Handbook of Agriculture as Practised in the Anglo-Egyptian Sudan, London, 941-955

Vliet, J. van der 2002: Gleanings from Christian Northern Nubia, JJP XXXII, 175-194

Vliet, J. van der 2018: The Christian Epigraphy of Egypt and Nubia, Ed. Dekker, R., VCSS CS1070, London-New York

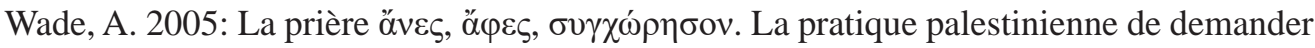
l'absolution pour la communion solitaire et quotidienne. Lex orandi pour une

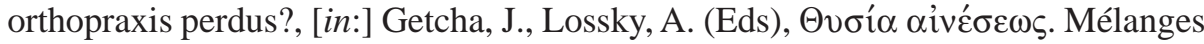
liturgiques offerts à la mémoire de l'archevêque Georges Wagner (1930-1993), Analecta Sergiana 2, Paris, 431-435 


\section{ÉTUDES et TRAVAUX XXXII / 2019}

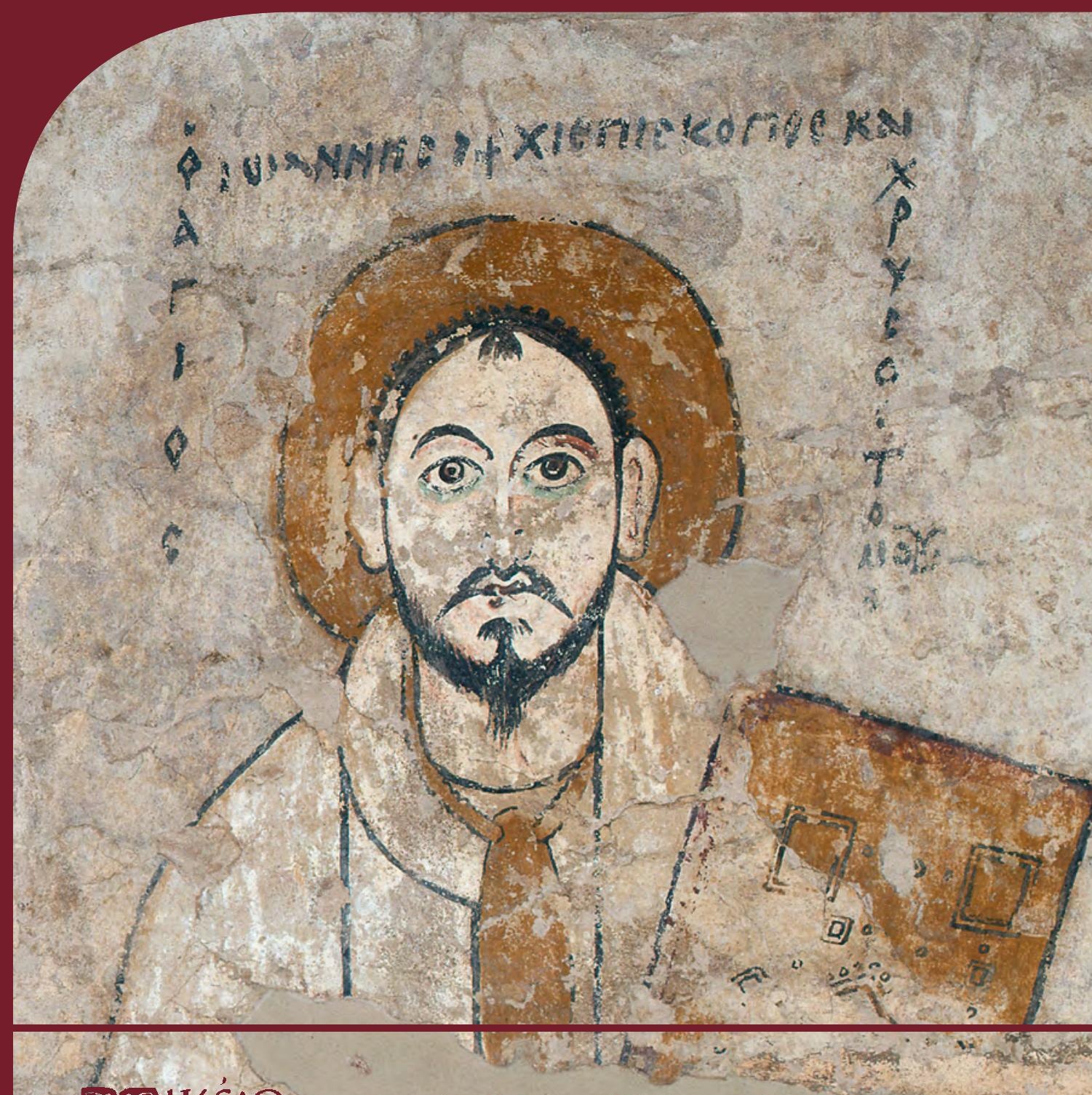

BOMIKSiO Institut des Cultures Méditerranéennes et Orientales ED2A PAN de l'Acácémie Polonaise des Sciences 


\title{
COMITÉ DE RÉDACTION SCIENTIFIQUE
}

Maciej Makowski - rédacteur en chef Jadwiga Iwaszczuk - rédacteur

Maciej G. Witkowski - rédacteur

Agnieszka Ryś - sécretaire de la rédaction

Bogdan Żurawski - rédacteur thématique du volume

CONSEIL SCIENTIFIQUE DU JOURNAL

M. Kobusiewicz (IAE PAN, Warszawa), E. Laskowska-Kusztal (IMOC PAS, Warszawa),

D. Michaelides (University of Cyprus, Nicosia),

J.Ch. Moretti (IRAA-MOM, Université de Lyon 2/CNRS),

D. Raue (Ägyptisches Museum der Universität Leipzig), P. Reynolds (ICREA, España),

D. Welsby (British Museum, London)

\section{COMITÉ SCIENTIFIQUE DE LECTURE}

D.E. Arnold (Wheaton College/The Field Museum, Chicago), H.D. Baker (University of Toronto),

P. Ballet (ArScAn-ESPRI, Université Paris Nanterre), Ch. Barber (Princeton University),

N. Beaux-Grimal (IFAO, Caire/Collège de France, Paris), A. Boud'hors (CNRS, IRHT, Paris),

J. Budka (Ludwig-Maximilians-Universität München), R. David (SFDAS),

A. Delattre (CPEG, Bruxelles), A. Dodson (University of Bristol),

E. Fogliadini (Facoltà Teologica dell'Italia Settentrionale, Milan),

V. Francigny (CNRS/CRES, Paris), L. Gabolde (CNRS), C. Gobeil (Egypt Exploration Society, London),

N. Hamdi (UCL, Louvain), J. den Heijer (CIOL/INCAL, Louvain-la-Neuve),

S. Ikram (American University in Cairo), Ch. Leitz (Universität Tübingen), S. Ortisi (Universität München),

E. Rova (Università Ca' Foscari Venezia), G. Ruffini (Fairfield University),

A. Sasson (San Diego Natural History Museum), H. Satzinger (Universität Wien),

S.M. Schellinger (The Ohio State University, Columbus), G. Schreiber (Eötvös Loránd University, Budapest),

E. Teeter (University of Chicago), S. Torallas-Tovar (University of Chicago),

Y. Tristant (Macquarie University, Sydney), V. Vaelske (independent researcher),

H. Vymazalová (Charles University, Prague), P. Weschenfelder (Universität Wien),

B. Williams (University of Chicago/PCMA UW, Warszawa),

K. Winther-Jacobsen (The Danish Institute at Athens), E. Zacharopoulou (University of Johannesburg),

P. Grotowski (UPJPII, Kraków), E. Papuci-Władyka, J. Śliwa (IA JU, Kraków), A. Ćwiek (IA AMU, Poznań),

K.O. Kuraszkiewicz, M. Pinker (FOS UW, Warszawa), Ł. Niesiołowski-Spanò (IH UW, Warszawa),

M. Gawlikowski, Mahmoud El-Tayeb (PCMA UW, Warszawa), S. Rzepka (IA UW, Warszawa)

\author{
RÉDACTION TECHNIQUE \\ Monika Wesołowska
}

REVUE DES TEXTES ANGLAIS

Jo Harper 
ÉTUDES et TRAVAUX

XXXII 
INSTYTUT KULTUR ŚRÓDZIEMNOMORSKICH I ORIENTALNYCH POLSKIEJ AKADEMII NAUK

\title{
STUDIA i PRACE
}

\author{
XXXII
}

gू IKŚiO

ESAN

WARSZAWA

2019 
INSTITUT DES CULTURES MÉDITERRANÉENNES ET ORIENTALES DE L’ACADÉMIE POLONAISE DES SCIENCES

\section{ÉTUDES et TRAVAUX}

XXXII

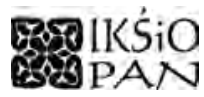

VARSOVIE

2019 
Publication scientifique financée dans le cadre du programme du Ministre de la Science et de l’Éducation Supérieure

« Programme National de Développement de l’Humanistique » pour les années 2016-2021 (projet no $3 b H 150099$ 83)

\title{
TI NARODOWY PROGRAM ROZWOJU HUMANISTYKI
}

\author{
Copyright $(\mathbb{C}$ \\ Instytut Kultur Śródziemnomorskich i Orientalnych PAN \\ et les Auteurs \\ Warszawa 2019
}

\begin{abstract}
ISSN 2084-6762
(avant 2011 : 0079-3566)

e-ISSN 2449-9579

Version première en papier, imprimée en Pologne - 150 copies

Version électronique accessible sur

http://www.etudesettravaux.iksiopan.pl
\end{abstract}

Édition: Polskie Towarzystwo Historyczne et Wydawnictwo Neriton, Warszawa

Conception générale de couverture : J. Iwaszczuk

Photo de couverture : P. Ligier ; courtoisie du Musée National de Varsovie

(Saint Jean Chrysostome, peinture, cathédrale de Faras). 


\section{Table des matières}

Editorial: Quid novi ex Nubia (par Bogdan Żurawski) ............................................... 7

Bibliography of Professor Stefan Jakobielski ................................................................ 13

Aneta Cedro, Bogdan Żurawski

Living with the Past in Modern Sudanese Village. Traditional Pottery Production

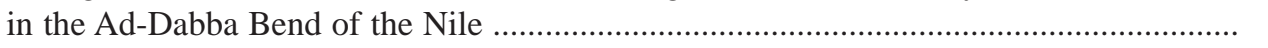

DAVID N. EDWARDS

A Possible Monastery and the 'Upper Maqs’ at Ukma-Akasha West? ............................ 53

Vincent W.J. van GeRven OeI

An Old Nubian Curse from the Faras Cathedral ........................................................ 81

Vincent W.J. van Gerven Oei, Adam Łajtar

Two Old Nubian Inscriptions from Akasha West ........................................................ 89

Vincent W.J. van Gerven Oei, Alexandros Tsakos

Rubrication Patterns in Two Old Nubian Manuscripts from Serra East .......................... 99

KAREL C. INNEMÉE

A Man in a Vessel, Once More .................................................................................. 111

KAREL C. INNEMÉE, Dobrochna ZielińSKA

Faces of Evil in Nubian Wall-Painting - An Overview ................................................ 121

ADAM ŁAJTAR

Epitaph of Merki Found in Hambukol ....................................................................... 145

MAGDALENA ŁAPTAŚ

Attributes, Vestments, Context and Inscription in the Identification of Nubian

Paintings: Proposing the 'Multi-Layer' Image Recognition Method ............................... 161

Grzegorz Ochala

Nubica Onomastica Miscellanea I: Notes on and Corrections to Personal Names

Found in Inscriptions from Faras 


\section{Robin SEIGNOBOS}

L'influence du Kitāb ahbār al-Nūba d'Ibn Sulaym al-Uswānī sur l'Histoire des églises et monastères d'Égypte d'Abū al-Makārim

JACQUES VAN DER VLIET

Exit Bishop Tamer - the Sequel. A New Edition of the Epitaph of Papsine alias Doulista (DBMNT 78) 